Research article

\title{
Social connectedness and job satisfaction in Mexican teleworkers during the pandemic: the mediating role of affective well-being
}

Daniel Arturo Cernas-Ortiz*

Profesor investigador, Facultad de Contaduría y Administración, Universidad Autónoma del Estado de México, Toluca, México. dacernaso@uaemex.mx

Lau Wai-Kwan

Associate Professor, Zeigler College of Business, Bloomsburg University of Pennsylvania, Bloomsburg, United States. wlau@bloomu.edu

\begin{abstract}
The purpose of this study was to examine the relationship between social connectedness outside of work and job satisfaction in Mexican teleworkers during the COVID-19 pandemic. The research method was correlational, non-experimental, and crosssectional. Employing an online, self-administered survey, the data were collected in a non-probabilistic sample of 214 individuals. The results suggest that the relationship between social connectedness outside of work and job satisfaction is positive and mediated by positive affective well-being. The mediating effect of positive affective well-being is not moderated by optimistic attributional style. Social connectedness outside of work is important to keep job satisfaction high. Therefore, organizations should facilitate a frequent interaction of their teleworkers with others outside the work domain.
\end{abstract}

Keywords: teleworking; social connectedness; job satisfaction; affective well-being; attributional style.

Conectividad social y satisfacción laboral en teletrabajadores mexicanos durante la pandemia: el papel mediador del bienestar afectivo

\section{Resumen}

El propósito de este estudio fue examinar la relación entre la conectividad social fuera del trabajo y la satisfacción laboral en teletrabajadores mexicanos durante la pandemia por COVID-19. El método de investigación fue correlacional, no experimental y transversal. Los datos se recolectaron en una muestra no probabilística de 214 individuos mediante una encuesta autoadministrada en línea. Los resultados sugieren que la relación entre la conectividad social fuera del trabajo y la satisfacción laboral es positiva y está mediada por el bienestar afectivo positivo. El efecto mediator del bienestar afectivo positivo no está moderado por el estilo atribucional optimista. Dada la importancia de la satisfacción laboral, las organizaciones deberían facilitar la interacción frecuente de sus empleados con personas fuera del trabajo.

Palabras clave: teletrabajo; conectividad social; satisfacción laboral; bienestar afectivo; estilo atribucional.

Conectividade social e satisfação no trabalho em teletrabalhadores mexicanos durante a pandemia: o papel mediador do bem-estar afetivo

\section{Resumo}

O objetivo deste estudo foi examinar a relação entre conectividade social fora do trabalho e a satisfação no trabalho em teletrabalhadores mexicanos durante a pandemia COVID-19. 0 método de pesquisa foi correlacional, não experimental e transversal. Os dados foram coletados em uma amostra não probabilística de 214 indivíduos por meio de um questionário online autoaplicável. Os resultados sugerem que a relação entre conectividade social fora do trabalho e satisfação no trabalho é positiva e mediada por bem-estar afetivo positivo. 0 efeito mediador do bem-estar afetivo positivo não é moderado pelo estilo de atribuição otimista. Dada a importância da satisfação no trabalho, as organizações devem facilitar a interação frequente de seus funcionários com pessoas fora do trabalho.

Palavras-chave: teletrabalho; conectividade social; satisfação no trabalho; bem-estar afetivo; estilo atribucional.

* Corresponding author.

JEL classification: M12; 131 .

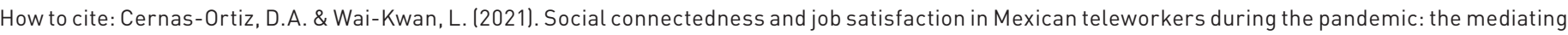
role of affective well-being. Estudios Gerenciales, 37(158), 37-48. https://doi.org/10.18046/j.estger.2021.158.4322

DOI: https://doi.org/10.18046/j.estger.2021.158.4322

Received: 25 -sep-2020

Accepted: 1-feb-2021

Available on line: 31-mar-2021

(c) 2021 Universidad ICESI. Published by Universidad Icesi, Colombia.

This is an open access article under the CC BY license (http://creativecommons.org/licenses/by/4.0/) 
family and friends during some of the harsher days of the pandemic (Televisa News, 2020). As implied, while some Mexican workers could have experienced low levels of SCOW while working from home, others may not. In turn, analyzing variation in teleworker SCOW levels is important because past research suggests that interacting and keeping in touch with other individuals promotes satisfaction and positive attitudes (Chan, Kalliath, Brough, Siu, O'Driscoll \& Timms, 2015). Due to its effects on such constructs as innovative performance (Ayala, Peiró-Silla, Tordera, Lorente \& Yeves, 2017), one critical attitude to examine in organizations is job satisfaction. Locke (1969) defines job satisfaction as the positive feelings of workers towards their job that depends on an evaluation of its characteristics.

Based on the above-stated antecedents, the general objective of this research was to examine the relationship between SCOW and job satisfaction in Mexican teleworkers during the COVID-19 pandemic. To go deeper into this purpose, we also aimed to investigate whether affective well-being (i.e., emotional reactions of people to their job; Van Katwyk, Fox, Spector \& Kelloway, 2000) mediates the relationship between SCOW and job satisfaction, and whether optimistic attributional style (i.e., the causal judgments that individuals make to explain the good and bad events that happen in their lives; Furnham, Sadka \& Brewin, 1992) moderates such a mediation effect. We analyze mediation and moderation in the relationship between SCOW and job satisfaction because Affective Events Theory (AET) (Ghasemy, Erfanian \& Gaskin, 2020; Weiss \& Cropanzano, 1996) suggests that affective states derived from work experiences and events influence job satisfaction. If SCOW could influence the occurrence of work-related events that make workers feel, for instance, happy or anxious, affective well-being should mediate the relationship between SCOW and job satisfaction. Furthermore, given optimistic attributional style effects on how events at work are interpreted and felt (Seligman, 2006), it might moderate the mediation role of affective well-being in the relationship between SCOW and job satisfaction in Mexican teleworkers.

This study is a cross-sectional, correlational, and non-experimental analysis of survey data collected during the heyday of telework in Mexico due to the COVID-19 pandemic. The results of our inquiry are valuable for research and practice. On the research side, this investigation contributes to understanding more clearly the relationship between social interactions with others outside of work and judgments of job satisfaction. More broadly, this study helps to clarify the contentious role of affective well-being and attributional style in the relationships between work-related events and attitudinal outcomes. Concerning managerial practice, this research's findings indicate that perhaps more than ever, if organizations want to keep a satisfied and motivated workforce, they should facilitate employee connectedness with family and friends.

The rest of this document is as follows: In the next section, we present the theoretical framework and the 
study hypotheses; next, we describe the methodology, followed by the results section; conclusions are presented at the end of the article.

\section{Theoretical framework}

Social connectedness is a strong predictor of motivation and well-being because it satisfies the human basic need of interpersonal relatedness (Deci \& Ryan, 1985). Certainly, dysfunctional relationships with individuals such as family members can have profound negative effects on mental and physical health (Carr \& Springer, 2010). However, being regularly connected with family and friends (who are not related to the job) is strongly associated with life satisfaction and happiness (Ambrey, Ulichny \& Fleming, 2017). More specifically, SCOW makes it less likely that people ruminate ${ }^{1}$ office issues after work hours and, hence, prevents them from high levels of stress (Cropley \& Purvis, 2003). If workrelated stress and job satisfaction are negatively associated (Ismail, Ghani, Subhan, Joarder \& Ridzuan, 2015), SCOW should be positively related to job satisfaction. Research on work-family enrichment supports this argument; it suggests that positive experiences in the family could improve affective reactions at work (Greenhaus \& Powell, 2006). Social interaction does not need to be face-to-face; webbased platforms enable workers to stay connected and such virtual interactions are associated with positive employee outcomes (Kügler, Dittes, Smolnik \& Richter, 2015).

Based on the above-stated arguments, we postulate the following hypothesis that directly links SCOW to job satisfaction. This hypothesis represents the base-line model against which the conditional mediating influence of affective well-being will be explored and tested:

- Hypothesis 1. SCOW and job satisfaction are positively related.

In the following paragraphs of this section, we use AET as an explanatory scaffold and focus our efforts on a more nuanced explanation of the mediating effects of affective well-being and its conditional influences depending on optimistic attributional style.

\subsection{SCOW, work-related events, and affect}

Although SCOW refers to events and experiences outside the work domain, it could trigger or influence job-related ones. On the whole, research on the work-life interface suggests that psychological resources generated in the family role (e.g., parental self-efficacyl are likely to influence performance in the work role (Greenhaus \& Powell, 2006). More specifically, being connected with family members and holding high-quality relationships with them is positively associated with job performance through their effects on psychological safety and well-being (Obrenovic, Jianguo, Khudaykulov \& Shafique-Khan, 2020). Taking

\footnotetext{
1 Rumination is a process of the mind characterized by self-reflection and repetitive and passive focus on moods and information (Treynor, Gonzalez \& Nolen-Hoeksema, 2003).
}

recourse to expectancy models such as Vroom's (1964) and even goal-setting theory (Latham, 2012), it is possible to say that attaining a difficult goal or being rewarded for superior performance are positive job-related events that elicit strong positive feelings such as happiness and pride. Similarly, being in touch with friends may be a source of positive job-related events. Friends, after all, are individuals to talk to, depend on for help and emotional support, or just have fun with (Rawlins, 2008). Being connected with friends is a crucial source of psychological well-being (Miller, 2014), which, in turn, can positively influence jobrelated events (e.g., goal attainment). Notoriously, per the same logic, strong relationships with family and friends may prevent individuals from performing poorly, or just not attaining their work goals successfully. Thus, not only would SCOW influence positive job-related events, but also may reduce the likelihood of experiencing negative ones, along with feelings usually associated with them such as anger and frustration.

The concept of affective well-being, nonetheless, has two dimensions: Positive affective well-being (PAWB) and negative affective well-being (NAWB). Positive and negative affect are two different, mostly independent, constructs that encompass different emotions, have different antecedents and consequences (Diener, Suh, Lucas \& Smith, 1999; Van Katwyk et al., 2000), and occur through different psychological and biological mechanisms (Watson, 2000). For instance, whereas not being happy would represent low positive affectivity rather than high negative affectivity, not feeling frustrated would represent low negative affectivity rather than high positive affectivity. Moreover, Diener et al. (1999) suggest that rewarding stimuli such as daily pleasures may be more strongly associated with variability in pleasant affect, and daily hassles would be more strongly related to variability in unpleasant affect. In fact, research suggests that events associated with telework have different associations with PAWB and NAWB (Anderson et al., 2015); hence, while SCOW would be positively related to PAWB, it would be negatively related to NAWB.

At this point, it is worth noting that, as an attitude, job satisfaction is an evaluative judgment encompassing affective and cognitive components (Brief \& Weiss, 2002), that is related to affective well-being (Van Katwyk et al., 2000). Elaborating on AET, Weiss and Beal (2005) argue that the relationship between affective states and job satisfaction may be down to one's personal memory for specific affective events coming into play when making satisfaction judgments. Although such a recalling is supplemented by dispositional influences and other information stored in long-term memory (Cropanzano \& Dasborough, 2015; Weiss \& Cropanzano, 1996), if affective states influence job satisfaction (Weiss \& Cropanzano, 1996), PAWB and NAWB will mediate the association between SCOW and job satisfaction.

However, two different mechanisms are worth explaining when it comes to the aforementioned mediating effects. When we suggest that PAWB mediates the association 
between SCOW and job satisfaction, we imply that PAWB transmits the positive effects of SCOW to job satisfaction. However, when we indicate that NAWB mediates the relationship between SCOW and job satisfaction, we mean that NAWB transmits the positive effect of SCOW to job satisfaction when it gets reduced. That is, SCOW-related events may reduce negative emotions lor the exposure to them), and that reduction would in turn translate into an increase in job satisfaction. Past studies suggest that positive and negative affectivity mediate relationships between psychological factors in opposite directions (e.g., Nejad, Besharat, Haddadi \& Abdolmanafi, 2011). The following hypotheses summarize these arguments:

- Hypothesis 2. PAWB mediates the positive association between SCOW and job satisfaction.

- Hypothesis 3. NAWB mediates the positive association between SCOW and job satisfaction.

\subsection{The moderating effect of optimistic attributional style}

Against the backdrop of $A E T$, an optimistic attributional style may moderate the mediating effects of PAWB and NAWB on the relationship between SCOW and job satisfaction. In other words, we posit that such mediating effects would be conditional upon the different levels of optimistic attributional style observed in Mexican teleworkers during the COVID-19 pandemic.

Abramson, Seligman and Teasdale (1978) introduced attributional style as a dispositional factor that influences vulnerability to depression. For example, if an employee gets a poor annual report from a supervisor, and $s /$ he attributes such an outcome to internal, stable, and global causes (e.g., low intelligence), such an individual is bound to experience strong negative emotions such as frustration and hopelessness (Furnham et al., 1992). In social science research, that pessimistic attributional style is negatively related to well-being relevant factors such as occupational self-efficacy (Cernas-Ortiz, 2018). Although attributions have been traditionally under-analyzed in organizational studies (Harvey, Madison, Martinko, Crook \& Crook, 2014), they undeniably influence happiness (Seligman, 2006), and are likely to have important effects on job satisfaction and subjective well-being (Proudfoot, Corr, Guest \& Dunn, 2009).

Attributional style is a habit of thought whereby a person is mostly an optimist if the negative events s/ he experiences are attributed to external, unstable, and specific causes, whereas the positives are attributed to internal, stable, and global reasons (Seligman, 2006). Weiner (2000) suggests that following a given event, one could initially feel happy or unhappy depending on whether it is positive or negative. He indicates that depending on its importance, foreseeability, and valence, events would elicit why questions to understand what was their cause. Therefore, following a positive work-related event influenced by SCOW (e.g., attaining a goal) there would be an effective reaction (e.g., happiness) that would be amplified or could even trigger other emotions le.g., pride), provided that the cause of the event is considered to be internal, stable, and global (e.g., ability). Similarly, if the event is not that positive le.g., being short of attaining the goal), the initial negative affective reaction (e.g., frustration) would lessen as the individual attributes it to external, unstable, and specific causes le.g., bad luck on that specific day). Notably, this sort of attributions may even prevent frustration from escalating to other, perhaps more pervasive sensations (e.g., hopelessness). Finally, research suggests that attributing a negative event le.g., failing a test) to stable rather than unstable causes elicits feelings of hopelessness and reduced behavioral efforts to succeed (Higgins \& LaPointe, 2012). Given that attributions play an important role in organizational phenomena (Weiner, 2019), and that they could amplify the mediating influences of PAWB and NAWB on the relationship between SCOW and job satisfaction, we postulate the following hypotheses:

- Hypothesis 4. Optimistic attributional style moderates the mediating effect of PAWB on the positive relationship between SCOW and job satisfaction in such a way that mediation will be stronger when optimistic attributional style is high.

- Hypothesis 5. Optimistic attributional style moderates the mediating effects of NAWB on the positive relationship between SCOW and job satisfaction in such a way that mediation will be stronger when optimistic attributional style is high.

Figure 1 presents our research model and summarizes the above-stated hypothetical relationships. The dotted line in the figure stands for a possible moderating effect of optimistic attributional style on the direct relationship between SCOW and job satisfaction. Such an association will be explored empirically in a later section of this document.

\section{Methodology}

\subsection{Participants and procedure}

Between May $15^{\text {th }}$ and Jun 30 $30^{\text {th }}, 214$ Mexican employees working from home answered an online survey; all employees were at home due to the coronavirus pandemic. Since the survey began almost two months after the Mexican government declared the national state of emergency, the respondents already had sufficient exposure to social restrictionsand arguably had experienced several work-related events influenced by SCOW. All 214 responses were valid because the online survey preempted participants from submitting without answering all questions. The rate of response was approximately $85 \%$ of the total number of people invited to participate in the study.

We employed a snowball sampling technique to collect the data. We began by kindly asking colleagues and acquaintances to answer the survey, and requested them to pass it on to some other colleagues/acquaintances so 
that they could answer it too. We asked our colleagues/ acquaintances to inform us of how many other individuals they invited to participate in the research. All respondents were aware that they would be answering an anonymous survey about their experiences with telework during the COVID-19 pandemic. The link to the survey website was sent by email. Their responses were recorded in the survey website repository. Once the data collection was over, the responses were downloaded to a spreadsheet to perform aggregate analysis.

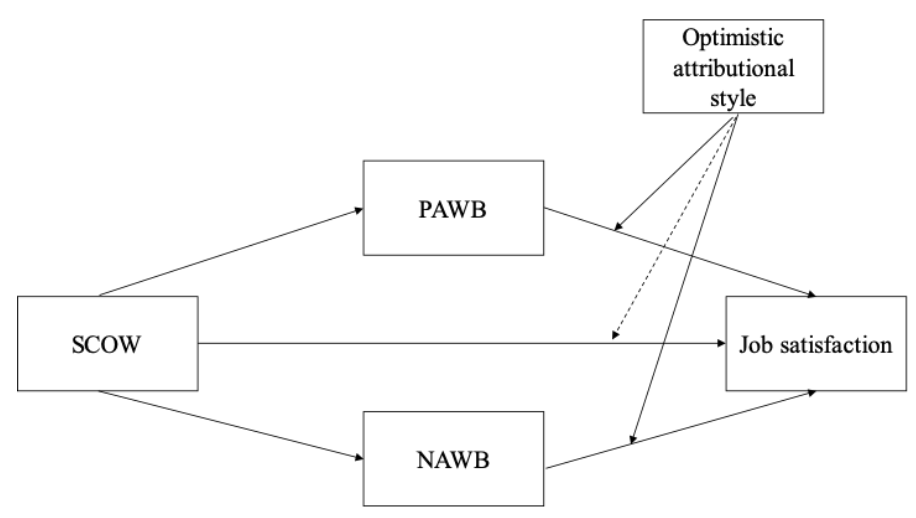

Figure 1. Research model

Source: own elaboration.

The majority of respondents were women (65.4\%), fulltime employees $(79 \%)$, and married $(52.8 \%)$. For more than half of the participants $(56.1 \%)$, the coronavirusrelated episode was their first teleworking experience. Concerning occupation, $47.2 \%$ of the respondents were education-sector employees, $41.1 \%$ were administrative staff associates in various sectors of economic activity, and the rest (11.7\%) were specialized technicians working for private-sector organizations. The average working experience was 15.57 years (standard deviation $=9.8$ ), and the average age was 41.28 years (standard deviation $=11$ ).

The sample of this study reasonably represents the population of teleworkers in Mexico during the COVID-19 pandemic. Recent statistics indicate that for the majority of Mexican teleworkers during the pandemic, this episode is (was) their first occasion working from home (Ramos-Pérez, 2020). Besides, women and full-time education-sector employees represent a considerable proportion of all Mexican teleworkers during the pandemic (NavarreteCazales, Manzanilla-Granados \& Ocaña-Pérez, 2020).

\subsection{Operationalization of variables}

\subsubsection{Social connectedness outside of work (SCOW)}

This variable was measured using the five-item scale adapted by Anderson et al. (2015), from Hawthorne (2006), to the context of telework. The scale had a stem question followed by the items in a Likert-type format anchored by 1 (I absolutely disagree) and 5 (/ absolutely agree). The stem question was adjusted to fit this research's context. The stem question was "Please answer the following questions about yourself outside of your work environment. During the weeks that I have been working from home..." A sample item is "I found it easy to get in touch with others when I needed to". The reliability estimate of the scale (a) was 0.70 in this study.

\subsubsection{Job satisfaction}

We measured this variable using the five-item job satisfaction index adapted from Brayfield and Rothe (1951). The stem question for these items was "Please answer the following questions considering your job in general, and NOT just the time you have been working from home". A sample item was "I feel very satisfied with my current job". The items were formatted in a Likert-type scale anchored by 1 (/ absolutely disagree) and 5 (/ absolutely agree). The reliability estimate of the scale (a) was 0.83 in this study.

\subsubsection{Positive and negative affective well-being (PAWB and NAWB)}

Respondents were asked to answer ten work-related items adapted by Anderson et al. (2015), from the original 30-item Job-Related Affective Well-Being Scale (JAWS) designed by Van Katwyk et al. (2000); five items measured PAWB and five other measured NAWB. For validity purposes, all items were intermixed in the survey. The stem question for these items was "Next, you will see ten items which describe different emotions that a person can experience during a workday. Please indicate the amount to which you think your job has made you feel each emotion today (ONLY today)". A sample item for PAWB was "My job made me feel happy" and a sample item for NAWB was "My job made me feel frustrated". All the items were presented in a Likert-type format anchored by 1 (Nothing) and 5 (A lot). The participants were instructed to answer the survey after 2:00 p.m., so as to facilitate the experience of several emotions during the workday. We asked respondents to focus on a specific day to tap freshly experienced emotions and avoid complex evaluations made on memories that, as time goes by, are progressively subject to memory and cognitive biases. Although studies that focus on short-lived emotional states usually make observations over several days, we relied on a one-time measurement episode due to practical constraints, and because research suggests that, albeit emotions change constantly, they show consistency over time (Cropanzano \& Dasborough, 2015). In this study, the reliability estimate (a) for PAWB was 0.90 , and for NAWB it was 0.79 .

The average value of the relevant items was obtained to construct our SCOW, job satisfaction, PAWB, and NAWB variables.

\subsubsection{Optimistic attributional style}

We used a reduced version of Furnham et al. (1992) Occupational Attributional Style Questionnaire (OASQ) 
for measuring this variable. The $O A S Q$ consists of five positive events and five negative events, for which the respondent is asked at first to vividly imagine him/herself in the situation and then write down the single most likely cause of the event. After that, the respondent has to answer nine questions concerning the cause $s /$ he wrote for each event; as each question represents a different attributional dimension, the OASQ measures 18 attributional dimensions (nine positive and nine negative). In the survey applied in this study, we were able to include only four positive events and four negative events: A sample positive event was "Imagine that you apply for a promotion and get it"; a sample negative event was "Imagine that you give an important talk in front of your colleagues and they react negatively". Being congruent with Seligman's (2006) conceptualization of attributional style, we only included three questions for each event: One question concerning internality, one question concerning stability, and one question about globality. As a result, we measured six attributional dimensions: Positive internality, negative internality, positive stability, negative stability, positive globality, and negative globality.

For all events, the question measuring internality was "To what extent was the cause due to something about you?" This item had to be answered on a scale anchored by 1 (Not at all due to me) and 4 (Totally due to me). The question measuring stability was "In the future, at work, will this cause again influence what happens?" which had to be answered on a scale anchored by 1 (Will always influence what happens) and 4 (Will never again influence what happens). The question measuring globality was "Is this cause something that affects only this particular situation or does it influence other areas of your life?" This question had to be answered on a scale anchored by 1 (Influences all areas of my life) and 4 (Influences just this situation).

Our operationalization of attributional style is in tune with that of Cernas-Ortiz (2018), who also used a reduced version of the OASQ, and with Seligman's (2006) recommendations to measure it. For all the positive events, and to keep congruence with the scores of internality lwhere 1 equals a less internal cause and 4 a more internal one), the respondent scores on stability and globality were reversecoded so that 1 denoted less stability and globality, and 4 more stability and globality. The opposite was done for negative events; stability and globality scores were left unaltered (1 denoting more of each dimension), but internality was reverse-coded so that 1 equaled more internality and 4 less internality. This way, we were able to gauge optimistic attributional style, which, as hinted above, implied attributing highly internal, stable, and global causes for positive events, and low internality, stability, and globality for negative ones. We averaged the respondent scores on each attributional dimension separately for the positive and the negative events. Average scores on internality, stability, and globality for positive events were, in turn, averaged to obtain what we called "net positive attributions score". Average scores on internality, stability, and globality for negative events were also averaged to obtain "net negative attributions score". Finally, optimistic attributional style was obtained by calculating the average of net positive attributions score and net negative attributions score. Reliability coefficients (a) in this study were as follows: Positive internality $=0.72$, negative internality $=0.70$, positive stability $=0.78$, negative stability $=0.77$, positive globality $=$ 0.86 and negative globality $=0.86$.

It is worth noting that the use of different stem questions and verbal anchors in different measures helped us to prevent common method biases. Also, in the online survey, different scales were presented in various response formats (e.g., dropdown and multiple choice). Podsakoff, MacKenzie, Lee and Podsakoff (2003) suggest this kind of methodological separations as a procedural remedy for controlling common method biases.

Consistent with Brislin (1970) suggestions, all scales were translated into Spanish (Mexican) from their original in English following a back-translation procedure. That is, all items were first translated into Spanish by a bilingual person; then, another bilingual person translated the items back to English. The original and back-translated English versions were compared to detect and correct discrepancies in meaning. The items were deemed adequate for use when no further discrepancies were detected (only two iterations).

\subsection{Data analysis}

Validity was assessed through confirmatory factor analysis (CFA) in LISREL $®$ (8.8). Descriptive statistics were calculated for each construct along with bivariate correlations to have a general overview of the data. We used the PROCESS macro (Hayes, 2013) in SPSS ${ }^{8}(20)$ to test the above-presented hypotheses. PROCESS runs a regressionbased algorithm that allows the parallel analysis of different mediators and helps to analyze moderated mediation. PROCESS yields an output that is easy to interpret and very thorough concerning the analysis of mediation, moderation, and conditional processes.

\section{Results}

\subsection{Validity assessment}

Validity was assessed for SCOW, PAWB, NAWB, and job satisfaction together in a two-step fashion. First, all items were forced to load onto one unique factor. Next, all items were instructed to load onto the one construct they were supposed to according to the above-described measurement scales. Table 1 suggests that whereas the one-factor solution had a poor fit to the data $|C F|<0.95$, RMSEA $>0.08, \chi^{2} / d f>3$ ), the four-factor solution fitted the data much better (CFI $>0.95, R M S E A<0.08, \chi^{2} / d f<3$ ). Also, the test of changes in Chi-squared $\left(\triangle \chi^{2}\right)$ between the onefactor and the four-factor solutions indicates that there were significant differences between them. These results, on the whole, indicated that the data converged in four constructs 
that discriminate adequately among them. No changes to the four-factor solution were made based on modification indexes suggested by LISREL.

Table 1. Validity Assessment of SCOW, PAWB, NAWB, and job satisfaction

\begin{tabular}{|c|c|c|c|c|c|c|}
\hline Model/Indicator & $x^{2}$ & df & $\mathrm{CFI}$ & RMSEA & $\chi^{2} / \mathrm{df}$ & $\Delta \chi^{2}$ \\
\hline $\begin{array}{l}\text { One-factor } \\
\text { solution }\end{array}$ & $821.73^{* * *}$ & 170 & 0.87 & 0.13 & 4.83 & \\
\hline $\begin{array}{l}\text { Four-factor } \\
\text { solution }\end{array}$ & $337.52^{* * *}$ & 164 & 0.96 & 0.07 & 2.06 & $484.21^{* * *}$ \\
\hline
\end{tabular}

In addition, average variance extracted indexes (AVE) were calculated to back up our convergent validity claims. AVE indexes were calculated following the process described in Hair, Black, Babin, Anderson and Tatham (2006). The AVE indexes of SCOW, PAWB, NAWB, and job satisfaction were all above the 0.50 threshold indicated by these authors, suggesting adequate convergent validity.

The six dimensions used to gauge optimistic attributional style were factor-analyzed together following the same two-step process described above. The results of this analysis are shown in Table 2. In this case, again, the one-factor solution fitted the data poorly $|C F|<0.95$, RMSEA > 0.08, $\chi^{2} / d f>3$ ); however, although the sixfactor solution had a better fit (CFI $=0.91, R M S E A=0.09$, $\left.\chi^{2} / d f=2.64\right)$, its fit indexes were just borderline good. Five changes were made to the six-factor solution based on the top-five largest modification indexes suggested by LISREL; however, fit indexes did not improve considerably $(C F)=0.92$, RMSEA $=0.08, \chi^{2} / d f=2.36$ ). On account of these results, AVE indexes were calculated to determine convergent validity; they were as follows: Positive internality $=0.41$, negative internality $=0.42$, positive stability $=0.51$, negative stability $=0.52$, positive globality $=0.61$ and negative globality $=0.60$. Thus, while the attributional dimensions of stability and globality were deemed valid, internality had a more dubious status. That said, we considered that our measure of optimistic attributional style was reasonably good; however, results should be interpreted with caution.

Table 2. Validity assessment of attributional dimensions

\begin{tabular}{|c|c|c|c|c|c|c|}
\hline Model/Indicator & $x^{2}$ & $d f$ & $\mathrm{CFI}$ & RMSEA & $\begin{array}{l}x^{2} / \\
d f\end{array}$ & $\Delta \mathrm{x}^{2}$ \\
\hline One-factor solution & $2304.87^{* * *}$ & 252 & 0.68 & 0.20 & 9.15 & \\
\hline Six-factor solution & $624.85^{* * *}$ & 237 & 0.91 & 0.09 & 2.64 & $1680^{* * *}$ \\
\hline $\begin{array}{l}\text { Adjusted six-factor } \\
\text { solution (based } \\
\text { on modification } \\
\text { indexes) }\end{array}$ & $547.34^{* * *}$ & 232 & 0.92 & 0.08 & 2.36 & $77.51^{* * *}$ \\
\hline
\end{tabular}

As described in Lindell and Whitney (2001), we examined the presence of common method biases in our data. We did not find significant common method variance issues at the 0.05 level.

\subsection{Descriptive statistics}

Table 3 shows means and standard deviations for SCOW, PAWB, NAWB, job satisfaction, and our composite measure of optimistic attributional style. As observed in the table, the mean values of job satisfaction were higher than those of the other variables. Also, indicating that positive emotions were more prevalent among the respondents than negative ones, PAWB mean values were higher than NAWB's. SCOW mean values seem to be reasonably high indicating that respondents kept a good level of social connectedness outside of work during the period indicated in the stem question of that variable. Concerning optimistic attributional style, because its mean value is higher than 2 (the theoretical mean of the variable), it can be said that respondents tended to keep an optimistic outlook on work and life.

Table 3. Descriptive statistics and bivariate correlations

\begin{tabular}{|c|c|c|c|c|c|c|c|}
\hline \multicolumn{2}{|c|}{ Variables } & \multirow{2}{*}{$\begin{array}{l}\text { Mean } \\
3.72\end{array}$} & \multirow{2}{*}{$\begin{array}{l}\text { Stdv. } \\
0.66\end{array}$} & \multirow[t]{2}{*}{1} & \multirow[t]{2}{*}{2} & \multirow[t]{2}{*}{3} & \multirow[t]{2}{*}{4} \\
\hline 1 & $\begin{array}{l}\text { Social } \\
\text { connectedness } \\
\text { outside of } \\
\text { work (SCOW) }\end{array}$ & & & & & & \\
\hline 2 & Job satisfaction & 4.01 & 0.69 & $0.27^{* * *}$ & & & \\
\hline 3 & $\begin{array}{l}\text { Positive } \\
\text { affective } \\
\text { well-being } \\
\text { (PAWB) }\end{array}$ & 3.83 & 0.74 & $0.28^{* * *}$ & $0.59 * * *$ & & \\
\hline 4 & $\begin{array}{l}\text { Negative } \\
\text { affective } \\
\text { well-being } \\
\text { (NAWB) }\end{array}$ & 2.05 & 0.80 & $-0.31^{* * *}$ & $-0.37 * * *$ & $-0.58^{* * *}$ & \\
\hline 5 & $\begin{array}{l}\text { Optimistic } \\
\text { attributional } \\
\text { style }\end{array}$ & 2.81 & 0.32 & 0.12 & $0.14^{*}$ & 0.07 & -0.01 \\
\hline
\end{tabular}

Table 3 suggests that SCOW had medium-sized correlations with job satisfaction, PAWB, and NAWB (negative in this case). Also, and consistent with our theory, job satisfaction had a strong positive association with PAWB, and a medium-sized negative one with NAWB. PAWB and NAWB were negatively correlated, as they should be. The only significant correlation of optimistic attributional style was with job satisfaction. Prima facie, attributions seem to have significant relationships with broad attitudinal factors (i.e., job satisfaction), but weak ones with short-lived emotional states.

\subsection{Hypotheses testing}

Hypothesis 1 suggests a positive relationship between SCOW and job satisfaction. Table 4 shows a summary of the PROCESS output. In the table, the total effect of SCOW on job satisfaction is positive and significant. This evidence supports Hypothesis 1.

Hypotheses 2 and 3 suggest that PAWB and NAWB mediate the relationship between $\mathrm{SCOW}$ and job satisfaction. Table 4 shows that while the direct effect of SCOW on job satisfaction is non-significant, the indirect effect (total) is significant and accounts for $59 \%$ of the total relationship 
According to Hayes (2013), there is evidence of moderated

between SCOW and job satisfaction. Hitherto, the evidence suggests that PAWB and NAWB together transmit the positive effect of SCOW on job satisfaction significantly and to a great extent. However, looking closely at the results in Table 4, the mediating effect of PAWB is significant but the mediating effect of NAWB is not; indeed, while the mediating effect of PAWB accounts for $57 \%$ of the total effect of SCOW on job satisfaction lalmost the entire total mediating effect), NAWB accounts for only $2 \%$. Based on this evidence, Hypothesis 2 is supported and Hypothesis 3 is rejected. An analysis not shown in the table confirms that the mediating effects of PAWB and NAWB are significantly different between them $(p<0.001)$.

Table 4. Total, direct, and indirect effects of SCOW on job satisfaction

\begin{tabular}{|c|c|c|}
\hline Effects & \multicolumn{2}{|c|}{$\begin{array}{l}\text { Coefficients and } \\
\text { percentages }\end{array}$} \\
\hline \multirow[t]{2}{*}{ Total effect of SCOW on job satisfaction } & $0.28 * * *$ & \\
\hline & $(0.06)$ & \\
\hline \multirow[t]{2}{*}{ Direct effect of SCOW on job satisfaction } & 0.12 & \\
\hline & $(0.06)$ & \\
\hline Proportion of direct effect to total effect & $41 \%$ & \\
\hline \multirow{2}{*}{$\begin{array}{l}\text { Total indirect effect of SCOW on job } \\
\text { satisfaction through PAWB and NAWB }\end{array}$} & $0.17^{* * *}$ & \\
\hline & $(0.05)$ & \\
\hline $\begin{array}{l}\text { Proportion of the total effect that is } \\
\text { mediated by both PAWB and NAWB }\end{array}$ & $59 \%$ & \\
\hline \multirow[t]{2}{*}{ Indirect effect through PAWB } & & $0.16^{* * *}$ \\
\hline & & $(0.04)$ \\
\hline $\begin{array}{l}\text { Proportion of the total effect that is } \\
\text { mediated by PAWB }\end{array}$ & & $57 \%$ \\
\hline \multirow[t]{2}{*}{ Indirect effect through NAWB } & & 0.00 \\
\hline & & (0.02) \\
\hline $\begin{array}{l}\text { Proportion of the total effect that is } \\
\text { mediated by NAWB }\end{array}$ & & $2 \%$ \\
\hline
\end{tabular}

Before describing the testing of hypotheses 4 and 5 , it is worth noting that, to compute moderated mediation (which is what the hypotheses in mention entail), PROCESS runs a series of regression models. Each model has different main terms and interactions. The obtained regression coefficients are then utilized by PROCESS to calculate conditional direct and indirect effects (through the mediator) of the independent variable on the dependent variable at different values of the moderator. The procedure is called Conditional Process Analysis lor Conditional Process Modeling) and is described in Hayes (2013). PROCESS (in SPSS) produces an output with all such models and calculations. Table 5 shows a summary of such an output.

In Table 5, one can observe the direct effect of SCOW (the non-mediated part) on job satisfaction at $16^{\text {th }}, 50^{\text {th }}$, and $84^{\text {th }}$ percentile values of optimistic attributional style. These percentile values are PROCESS default option. In Table 5, the indirect effects of SCOW on job satisfaction through PAWB and NAWB are also shown at the indicated percentile values. mediation if the indirect effects change significance levels at the different percentile values of the moderator. That is, moderated mediation is said to exist if, for example, any given indirect effect is significant at the $16^{\text {th }}$ percentile, but is not so at the $50^{\text {th }}$ and $84^{\text {th }}$ percentiles. Hayes (2013) argues that there is no evidence of moderated mediation if the indirect effects remain significant (or non-significant) at all the percentile values of the moderator ${ }^{2}$. In addition, Hayes (2013) recommends taking a look at the index of moderated mediation and its bootstrapped confidence interval. There is evidence of moderated mediation if the confidence interval is entirely above zero for a positive index, or entirely below zero for a negative one.

Hypotheses 4 and 5 suggest that optimistic attributional style moderates the mediating effects of PAWB and NAWB on the relationship between SCOW and job satisfaction. Table 5 shows the indirect effect of SCOW on job satisfaction through PAWB and NAWB, respectively, at indicated percentile values of optimistic attributional style. As observed in the table, whereas the mediating effects of PAWB were significant at all percentile values of the moderating variable, the effects of NAWB remained non-significant at all percentile values. In sum, the evidence in Table 5 suggests that optimistic attributional style does not moderate the mediating effects of PAWB and NAWB on the relationship between SCOW and job satisfaction. The index of moderated mediation for PAWB was -0.11 and its confidence interval ranged from -0.27 to 0.11 . The index of moderated mediation for NAWB was 0.09 , and its confidence interval was -0.05 to 0.27 . Hypotheses 4 and 5 are, thus, rejected.

As an additional note, Table 5 suggests that while the direct effect of SCOW on job satisfaction is non-significant at the $16^{\text {th }}$ and $50^{\text {th }}$ percentile values of optimistic attributional style, it is significant at the $84^{\text {th }}$ percentile. Therefore, optimistic attributional style moderates the direct relationship (i.e., the non-mediated part) between SCOW and job satisfaction.

The above-presented results did not vary significantly when the respondent sex, age, occupation, and average working experience were controlled for in the analyses carried out by PROCESS.

\section{Conclusions}

In Mexico, as in other parts of the world, the COVID-19 pandemic has prompted many organizations to implement telework widely. While not being a novelty that working remotely might cause social isolation feelings (Gallatin, 2018), interacting and keeping in touch with individuals outside of work could make up for a precarious interaction with work colleagues. After all, interacting with family members reduces rumination and negativity (Cropley \& Purvis, 2003; Chow \& Lo, 2017), which may help to keep job satisfaction high. The coronavirus pandemic, however, has disrupted social connectedness to various degrees; albeit feelings of solitude have loomed large on the lives of millions of Mexicans during

${ }^{2}$ For the mathematical details of moderated mediation, please refer to chapters 10 and 11 of Hayes (2013). Also, more details on the results presented in Table 5 are available from the authors upon request. 
the crisis, some individuals have managed to remain connected with their families and friends making it possible to maintain positive attitudes towards their jobs.

Table 5. Direct and indirect effects of SCOW on job satisfaction at the $16^{\text {th }}$, $50^{\text {th }}$, and $84^{\text {th }}$ percentile values of optimistic attributional style

\begin{tabular}{|c|c|c|}
\hline Effects & Percentile & Coefficients \\
\hline \multirow[t]{6}{*}{ Direct effect of SCOW on job satisfaction } & $16^{\text {th }}$ & 0.05 \\
\hline & & (0.08) \\
\hline & $50^{\text {th }}$ & 0.11 \\
\hline & & $(0.06)$ \\
\hline & $84^{\text {th }}$ & $0.17 *$ \\
\hline & & (0.08) \\
\hline \multirow{6}{*}{$\begin{array}{l}\text { Indirect effect of SCOW on job } \\
\text { satisfaction through PAWB }\end{array}$} & $16^{\text {th }}$ & $0.19 * * *$ \\
\hline & & (0.05) \\
\hline & $50^{\text {th }}$ & $0.16^{* * *}$ \\
\hline & & $(0.04)$ \\
\hline & $84^{\text {th }}$ & $0.13^{* * *}$ \\
\hline & & $(0.05)$ \\
\hline \multirow{6}{*}{$\begin{array}{l}\text { Indirect effect of SCOW on job } \\
\text { satisfaction through NAWB }\end{array}$} & $16^{\text {th }}$ & -0.02 \\
\hline & & $(0.04)$ \\
\hline & $50^{\text {th }}$ & 0.00 \\
\hline & & (0.03) \\
\hline & $84^{\text {th }}$ & 0.03 \\
\hline & & (0.03) \\
\hline
\end{tabular}

Note: numbers within parenthesis are standard errors. Percentile values: $16^{\text {th }}=2.50 ; 50^{\text {th }}=2.80 ; 84^{\text {th }}=3.08$.

$*=p<0.05 ;^{* *}=p<0.01 ;{ }^{* * *}=p<0.001$

Source: own elaboration.

The general purpose of this study was to test the relationship between SCOW and job satisfaction in a sample of Mexican teleworkers during the coronavirus outbreak. The results of the empirical investigation suggest that such a relationship is positive and statistically significant. This finding contributes to current knowledge. First, research on job attitudes has traditionally been concerned about the effects of interaction with others in the workplace (Gillespie et al., 2016), but much less on the influence that interactions with others outside of work has on job attitudes. As our results suggest, albeit possibly due to different mechanisms, both in-work and out-of-work interactions are relevant to the satisfaction of teleworkers. Secondly, we contribute to the research literature on the work-family interface; Greenhaus and Powell (2006) contented that family interactions influence job performance and, in turn, positive affect in the workplace. Given that telework blurs the line between work and family. Powell, Greenhaus, Allen and Johnson (2019) highlighted the need to investigate work-family dynamics in teleworkers. Shedding some light on such a research gap, we argued that SCOW (which encompasses family and friends connections and interactions) is likely to influence job-related events (e.g., high performance), and we found that SCOW is associated with job satisfaction lan affect-related construct) in the context of telework during the pandemic.
In addition, we tested the mediating effect of emotional states on the link between SCOW and job satisfaction. By taking recourse to AET, we argued that SCOW could influence positive work-related events that elicit shortlived emotional states. Given that such states are usually associated with job satisfaction (Ghasemy et al., 2020) they could transmit the positive influence of ScOW on that attitude. We argued, nevertheless, that such a transmission would have two mechanisms: PAWB would transmit the positive effects of SCOW on job satisfaction by an increase in positive emotions (due to SCOW positively affecting work-related events), and NAWB would do so by a decrease in negative ones. The results of this investigation suggest that the positive effects of SCOW on job satisfaction are transmitted by an increase in PAWB but not by a decrease in NAWB. While this finding is in tune with past research suggesting that positive and negative affect are mostly independent constructs with different antecedents and consequences (Diener et al., 1999); it suggests that if SCOW is to affect job satisfaction, it will most likely be only by eliciting positive emotions. Interestingly, our findings indicate that although SCOW is negatively related to NAWB, and thus an increase in SCOW may reduce negative emotions while teleworking, such a reduction is likely not to be translated into an increase in job satisfaction. However revealing, this finding is at odds with research suggesting that negative events and emotions have more potency to affect a broad range of psychological phenomena than their positive counterparts (Soroka, Fournier \& Nir, 2019).

In this study, it was also examined whether optimistic attributional style moderates the mediating effects of PAWB and NAWB on the relationship between SCOW and job satisfaction. The results did not support such a proposition. Instead, they suggest that no matter the level of optimistic attributions an individual could make following an emotion caused by a work-related event influenced by SCOW, the mediating effects of PAWB and NAWB remain very similar. From a research point of view, this finding is unexpected given that attributions have demonstrated effect sizes comparable to other individual difference variables le.g., BIG five personality dimensions), which are more commonly used as predictors of workplace outcomes (Harvey et al., 2014). From a practice-wise point of view, such a finding is disappointing because assessing individual differences helps to identify the ones who are more apt to telework effectively (Anderson et al., 2015). Importantly, in our case, attributional style is an individual difference variable that, although rather stable, is amenable to change through therapeutic intervention and/or self-help strategies (Seligman, 2006). However, one reason for our results may be that, as Weiner (2000) suggests, to trigger cognitions (e.g., attributions) an event should be unexpected and important. Maybe the participants of this study based their responses on events that were neither that unexpected nor very important to them. Nonetheless, what we did find is the direct effect of SCOW on job satisfaction being stronger and significant at high levels of optimistic attributional style. It seems 
that following some work-related events influenced by SCOW, individuals think of their possible causes, being the internal, stable, and global qualities of those causes that influence job satisfaction judgments. After all, while PAWB and NAWB are purely emotional states, job satisfaction has an important cognitive component that is more directly attuned with other cognitive factors such as attributional style.

This study has some practical ramifications. Even if convenient for some people, telework is not for everyone; as said before, telework may cause social isolation and low job satisfaction; that is when SCOW comes in. As the COVID-19 pandemic goes on, companies should facilitate employee connectedness with others outside of their job. For example, by taking actions to reduce work-family conflict, organizations would be investing in employee affective well-being by making possible more frequent socialization with family and friends. Anecdotic experiences, heard from some Mexicans pushed to telework during the pandemic, indicate that certain bad practices prevalent in the traditional workplace le.g., ineffective use of time reflected in long frequent meetings), have been transferred to the home le.g. long frequent videoconferences over ZOOM). By actively addressing such issues, organizational actions would first be reflected in more positive and less negative work-related emotions, and, eventually, in higher job satisfaction during the COVID-19 pandemic, and possibly other crises. There are several practices that organizations can implement to facilitate work-life balance (and SCOW, indirectly), such as scheduling meetings at reasonable hours, having flexible working hours, and cutting back on meetings. Moreover, budget permitting, organizations might provide some employees (e.g., the ones with low levels of optimism), cognitive-behavioral training to change their attributional style. This would be especially important during the current harsh times.

This study has some limitations that need to be addressed in future research. First of all, since different occupations may be better suited to teleworking during the COVID-19 and other crises, occupation is a factor that needs to be better controlled for in future research. Also, we employed a sampling technique that might induce self-selection biases in the data. Another limitation is that we did not implement a within-person research design; instead we relied on a between-person approach. This reduced our chances to tap the ebb and flow of affect and examine in more depth the influences of PAWB and NAWB on the relationship between SCOW and job satisfaction. Future works need to implement other sampling techniques and a within-person research design to examine variations in daily emotional states, and whether such variations play a significant role in the relationship between SCOW and job satisfaction. Future research studies could implement experimental and/or quasi-experimental designs to analyze our three rejected hypotheses in more depth. The dubious convergent validity of some attributional dimensions is also a limitation that needs to be addressed in future research. The internality dimension is a candidate for revision in Mexican culture.
Finally, telework has been an effective way to carry on organizational activities amid the human mobility restrictions brought about by the COVID-19 pandemic. The coronavirus outbreak has disrupted many Mexicans' usual social relationships and interactions. However, those individuals who have kept high levels of social connectedness outside of work have been prone to experience positive emotional states and, hence, mostly irrespective of their optimism levels, high job satisfaction. Mainly during the COVID-19 pandemic, and surely other crisis and non-crisis times, organizations should understand how important social connectedness outside of work is for individual affective well-being and workrelated attitudes. Consequently, organizations should help employees strike a work-life balance and facilitate their connectedness with people outside the job domain.

\section{Acknowledgements}

The authors express their sincere gratitude to this manuscript's anonymous reviewers for their ideas and substantial contributions to its improvement.

\section{Conflict of interest}

The authors declare no conflict of interest.

\section{References}

Abramson, L., Seligman, M. \& Teasdale, J. (1978). Learned helplessness in humans: Critique and reformulation. Journal of Abnormal Psychology, 87, 32-48. https://doi.org/10.1037/0021-843x.87.1.49

Ambrey, C., Ulichny, J. \& Fleming, C. (2017). The social connectedness and life satisfaction nexus: $A$ panel data analysis of women in Australia. Feminist Economics, 23(2), 1-32. http://dx.doi.org/10.1080/13545701.2016.1222077

Anderson, A., Kaplan, S. \& Vega, R. (2015). The impact of telework on emotional experience: When, and for whom does telework improve daily affective well-being? European Journal of Work and Organizational Psychology, 24(6), 882-897. https://doi.org/10.1080/1359432x.2014.966086

Aristotle (2003). Ética a Nicómaco (R. Rutiaga, Trans.). México: Grupo Editorial Tomo (Original work published ca. 350 B.C.E.).

Ayala, Y., Peiró-Silla, J. M., Tordera, N., Lorente, L. \& Yeves, J. (2017). Job satisfaction and innovative performance in young Spanish employees: Testing new patterns in the happy-productive worker thesis-A discriminant study. Journal of Happiness Studies, 18(5), 1377-1401. https://doi.org/10.1007/s10902-016-9778-1

Bailey, D. \& Kurland, N. (2002). A review of telework research: Findings, new directions, and lessons for the study of modern work. Journal of Organizational Behavior, 23, 383-400.

Barbalet, J.M. (1999). Boredom and social meaning. British Journal of Sociology, 50(4), 631-646. https://doi.org/10.1002/job.144

Brayfield, A.H. \& Rothe, H. (1951). An index of job satisfaction. Journal of Applied Psychology, 35, 207-311. https://doi.org/10.1037/h0055617

Brief, A. \& Weiss, H. (2002). Organizational behavior: Affect in the workplace. Annual Review of Psychology, 52, 279-307. https://doi.org/10.1146/annurev.psych.53.100901.135156

Brislin, R. W. (1970). Back-translation for cross-cultural research. Journal of Cross-Cultural Psychology, 1(3), 185-216. https://doi.org/10.1177/135910457000100301

Carr, D. \& Springer, C. (2010). Advances in families and health research in the 21st Century. Journal of Marriage and Family, 72, 743-761. https://doi.org/10.1111/j.1741-3737.2010.00728.x

Cernas-Ortiz, D.A. (2018). Pessimist explanatory style and occupational self-efficacy: A bicultural quantitative analysis. 
Nóesis Revista de Ciencias Sociales y Humanidades, 27(53), 1-16. https://doi.org/10.20983/noesis.2018.4.1

Chan, X., Kalliath, T., Brough, P., Siu, O., O’Driscoll, M. \& Timms, C. (2015). Work-family enrichment and satisfaction: The mediating role of self-efficacy and work-life balance. The International Journal of Human Resource Management, 27, 1755-1776. https://doi.org/10.1080/09585192.2015.1075574

Chow, K. \& Lo, B. (2017). Parental factors associated with ruminationrelated metacognitive beliefs in adolescence. Frontiers in Psychology, 8, 1-10. https://doi/ 10.3389/fpsyg.2017.00536

Cropanzano, R. \& Dasborough, M. (2015). Dynamic models of well-being: Implications of affective events theory for expanding current views on personality and climate. European Journal of Work and Organizational Psychology, 24(6), 844-847. https://doi.org/10.1080/1359432x.2015.1072245

Cropley, M. \& Purvis, L.M. (2003). Job strain and rumination about work issues during leisure time: A dairy study. European Journal of Work and Organizational Psychology, 12(3), 195-207. https://doi.org/10.1080/13594320344000093

Daniels, K., Lamond, D. \& Standen, P. (2000). Managing telework: An introduction to the issues. In K. Daniels, D. Lamond, and P. Standen (Eds.), Managing Telework: Perspectives from Human Resource Management and Work Psychology (pp. 1-8). London: Thomas Learning. https://doi.org/10.1108/pr.2001.30.5.602.1

Deci, E. \& Ryan, R. (1985). Intrinsic Motivation and Self-Determination in Human Behavior (1 ${ }^{\text {st }}$ ed.). New York: Plenum.

Diener, E., Suh, E., Lucas, R. \& Smith, H. (1999). Subjective well-being: Three decades of progress. Psychological Bulletin, 125(2), 276-302. https://doi.org/10.1037/0033-2909.125.2.276

Furnham, A., Sadka, V. \& Brewin, C. (1992). The development of an occupational attributional style questionnaire. Journal of Organizational Behavior, 13, 27-39. https://doi.org/10.1016/0003-6870(93)90101-e

Gallatin, K.A. (2018). Teleworker Isolation: Possible Effects of Workplace Relationships and Support (Doctoral dissertation). Available from ProQuest Dissertations \& Theses Global database. (UMI No. 13813301)

Ghasemy, M., Erfanian, M. \& Gaskin, J. (2020). Affective events theory as a theoretical lens for improving the working environment of academics in developing countries. Journal of Applied Research in Higher Education, 4, 1-20. https://doi.org/10.1108/JARHE-02-2020-0030

Gillespie, M., Balzer, W., Brodke, M., Garza, M., Gerbec, E., Gillespie, J., Gopalkrishnan, P., Lengyel, J., Sliter, K., Sliter, M., Withrow, S. \& Yugo, J. (2016). Normative measurement of job satisfaction in the US. Journal of Managerial Psychology, 31(2), 516-536. https://doi.org/10.1108/jmp-07-2014-0223

Golden, T. \& Veiga, J. (2005). The impact of extent of telecommuting on job satisfaction: Resolving inconsistent findings. Journal of Management, 31(2), 301-318. https://doi.org/10.1177/0149206304271768

Greenhaus, J. \& Powell, G. (2006). When work and family are allies: A theory of work-family enrichment. Academy of Management Review, 31(1), 72-92. https://doi.org/10.5465/amr.2006.19379625

Hair, J., Black, W., Babin, B., Anderson, R. \& Tatham, R. (2006). Multivariate Data Analysis (6th ed.). Upper Saddle River, NJ: Pearson Prentice-Hall.

Harvey, P., Madison, K., Martinko, M., Crook, T.R. \& Crook, T. (2014). Attribution theory in the organizational sciences: The road traveled and the path ahead. The Academy of Management Perspectives, 28(2), 128-146. https://doi.org/10.5465/amp.2012.0175

Hawthorne, G. (2006). Measuring social isolation in older adults: Development and initial validation of the friendship scale. Social Indicators Research, 77, 521-548. https://doi.org/10.1007/s11205-005-7746-y

Hayes, A. (2013). Introduction to Mediation, Moderation, and Conditional Process Analysis. A Regression-Based Approach (1 ${ }^{\text {st }}$ ed.). New York: The Guilford Press.

Higgins, N.C. \& LaPointe, M. (2012). Individual differences measure of attributions that affect achievement behavior. SAGE Open, 4, 1-15. https://doi.org/10.1177/2158244012470110

Ismail, A., Ghani, A., Subhan, M., Joarder, M. \& Ridzuan, A. (2015). The relationship between stress and job satisfaction: An evidence from Malaysian Peacekeeping Mission. Mediterranean Journal of Social Sciences, 6(4), 647-655. https://doi.org/10.5901/mjss.2015.v6n4s3p647
Kügler, M., Dittes, S., Smolnik, S. \& Richter, A. (2015). Connect me! Antecedents and impact of social connectedness in enterprise social software. Business and Information Systems Engineering, 57(3), 181-196. https://doi.org/10.1007/s12599-015-0379-z

Latham, G. (2012). Motivate employee performance through goal setting. In E. Locke (Ed.), Handbook of Principles of Organizational Behavior: Indispensable Knowledge for Evidence-Based Management Ipp. 161-178). New York: Willey. https://doi.org/10.1002/9781119206422

Lindell, M. \& Whitney, D. (2001). Accounting for common method variance in cross-sectional research designs. Journal of Applied Psychology, 86(1), 114-121. https://doi.org/10.1037/0021-9010.86.1.114

Locke, E. (1969). What is job satisfaction? Organizational Behavior and Human Performance, 4, 309-226. https://doi.org/10.1016/0030-5073(69)90013-0

Milenio (2020). Home Office por Coronavirus Lleva a $41 \%$ de Mexicanos a Trabajar Más. Retrieved on September 15th, 2020, from: https://www.milenio.com/negocios/home-office-por-coronaviruslleva-a-41-de-mexicanos-a-trabajar-mas

Miller, A. (2014). Friends Wanted. Monitor on Psychology, 45(1), 54-60. Retrieved from https://www.apa.org/monitor/2014/01/cover-friends

Navarrete-Cazales Z., Manzanilla-Granados, H. \& OcañaPérez, L. (2020). Políticas implementadas por el gobierno mexicano frente al COVID-19. El caso de la educación básica. Revista Latinoamericana de Estudios Educativos, 50, 1-10. https://www.redalyc.org/jatsRepo/270/27063237025/html/index.html

Nejad, E., Besharat, M., Haddadi, P. \& Abdolmanafi, A. (2011). Mediation effects of positive and negative affects on the relationship between perfectionism and physical health. Procedia-Social and Behavioral Sciences, 30, 176-1841. https://doi.org/10.1016/j.sbspro.2011.10.035

Obrenovic, B., Jianguo, D., Khudaykulov, A. \& Shanfique-Khan, M. (2020). Work-family conflict impact on psychological safety and psychological well-being: A job performance model. Frontiers in Psychology, 11, 1-18. https://doi.org/10.3389/fpsyg.2020.00475

Podsakoff, P. M., MacKenzie, S. B., Lee, J. Y. \& Podsakoff, N. P. (2003). Common method biases in behavioral research: A critical review of the literature and recommended remedies. Journal of Applied Psychology, 88 (5), 879-903. https://doi.org/10.1037/0021-9010.88.5.879

Powell, G., Greenhaus, J., Allen, T. \& Johnson, R. (2019). Advancing and expanding work-life theory from multiple perspectives. Academy of Management Review, 44(1), 54-71. https://doi.org/10.5465/amr.2018.0310

Proudfoot, J., Corr, P., Guest, D. \& Dunn, G. (2009). Cognitive-behavioral training to change attributional style improves employee well-being. job satisfaction, productivity, and turnover. Personality and Individual Differences, 46, 147-153. https://doi.org/10.1016/j.paid.2008.09.018

Ramos-Pérez, S. (2020). El futuro del teletrabajo. Revista Consultoría. Retrieved on December 24th, 2020, from: https://revistaconsultoria. com.mx/futuro-del-teletrabajo/

Rawlins, W. K. (2008). Friendship Matters: Communication, Dialectics, and the Life Course (2nd ed.). New York: Aldine De Gruyter.

Secretaría de Salud (2020). Jornada Nacional de Sana Distancia. Retrieved on September 15th, 2020, from: https://www.gob.mx/cms/uploads/ attachment/file/541687/Jornada_Nacional_de_Sana_Distancia.pdf

Seligman, M. (2006). Learned Optimism. How to Change Your Mind and Your Life (3rd ed.). New York: Vintage Books.

Soroka, S. N., Fournier, P. \& Nir, L. (2019). Cross-national evidence of negativity bias in psychophysiological reactions to news. Proceedings of the National Academy of Sciences, 116(38), 1-5. https://doi.org/10.1073/pnas.1908369116

Televisa News (2020). Videollamadas Acercan a Familias y Amigos Durante Aislamiento por Coronavirus. Retrieved on September $14^{\text {th }}, 2020$, from: https://noticieros.televisa.com/ultimas-noticias/ coronavirus-videollamadas-aislamiento-social-cuarentenaacerca-amigos-familia/

Treynor, W., González, R. \& Nolen-Hoeksema, S. (2003). Rumination reconsidered: A psychometric analysis. Cognitive Therapy and Research, 27, 247-259. https://doi.org/10.1023/A:1023910315561

Van Katwyk, P., Fox, S., Spector, P. \& Kelloway, K. (2000). Using the job-related affect well-being scale (JAWS) to investigate affective responses to work stressors. Journal of Occupational Health Psychology, 5(2), 219-230. https://doi.org/10.1037/1076-8998.5.2.219

Velasco, F. (2017). Understanding employee boredom among service employees: Qualitative insights and employee outcomes. Journal of Managerial Issues, 29(3), 278-293. 
Vroom, V. (1964). Work and Motivation (1 ${ }^{\text {st }}$ ed.). New York: Willey.

Watson, D. (2000). Mood and Temperament (1 $1^{\text {st }}$ ed.). New York: Guilford Press.

Weiner, B. (2000). Intrapersonal and interpersonal theories of motivation from an attributional perspective. Educational Psychology Review, 12(1), 1-14. https://doi.org/10.1007/978-1-4615-1273-8_2

Weiner, B. (2019). Wither attribution theory? Journal of Organizational Behavior, 40, 603-604. https://doi.org/10.1002/job.2398
Weiss, H. \& Beal, D. (2005). Reflections on affective events theory. In N.M. Ashkanasy, W.J. Zerbe and C.E.J. Härtel (Eds.), The Effect of Affect in Organizational Settings (Research on Emotion in Organizations) (pp. 1-21). Bingley: Emerald. https://doi.org/10.1016/s1746-9791(05)01116-8

Weiss, H. \& Cropanzano, R. (1996). Affective events theory: A theoretical discussion of the structure, causes and consequences of affective experiences at work. Research in Organizational Behavior, 18, 1-74. 